\title{
PENERAPAN MODEL PEMBELAJARAN COOPERATIVE LEARNING TIPE STAD UNTUK MENINGKATKAN HASIL BELAJAR DASAR-DASAR PAKAN TERNAK KELAS X ATR 2 SMK NEGERI 1 CANGKRINGAN
}

\author{
BETTY MAYASARI \\ SMK Negeri 1 Cangkringan, Sleman, Yogyakarta \\ e-mail: meces16@yahoo.co.id
}

\begin{abstract}
ABSTRAK
Guru mata pelajaran Dasar-dasar Pakan Ternak di SMK Negeri 1 Cangkringan merasakan rendahnya hasil belajar Dasar-dasar Pakan Ternak yang diperoleh siswa selama ini. Penggunaan suatu metode coopertif learning untuk meningkatkan hasil belajar siswa perlu dicoba. Penelitian ini bertujuan untuk miningkatkan hasil belajar siswa dengan menggunakan model pembelajaran Cooperative Learning tipe STAD pada mata pelajaran/kompetensi Dasar-dasar Pakan Ternak pada peserta didik SMK Negeri 1 Cangkringan kelas X ATR 2. Penelitian ini dilaksanakan pada bulan Agustus sampai dengan bulan November tahun 2019. Subyek penelitian tindakan kelas adalah peserta didik kelas X ATR 2 SMK Negeri 1 Cangkringan tahun pelajaran 2019/2020 yang berjumlah 35 orang peserta didik Dalam penelitian tindakan kelas ini pengambilan datanya menggunakan tes dan observasi. Dari hasil penelitian diperoleh data peningkatan hasil belajar siswa. Hasil pada siklus I diperoleh nilai ketuntasan belajar kelas sebesar $80 \%$ dan pada siklus II diperoleh nilai ketuntasan belajar klasikal sebesar 94,29\%. Dengan demikian dapat disimpulkan bahwa penerapan model pembelajaran cooperative learning tipe STAD untuk meningkatkan hasil belajar dasar-dasar pakan ternak kelas X ATR 2 SMK Negeri 1 Cangkringan.
\end{abstract}

Kata Kunci: Cooperative learning tipe STAD, Hasil Belajar, Pakan Ternak

\section{PENDAHULUAN}

Dasar dasar pakan ternak merupakan salah satu mata pelajaran dasar program keahlian Agribisnis Ternak Ruminansia. Dasar dasar pakan ternak termasuk kelompok mata pelajaran dasar program keahlian (C1) sehingga penguasaan kompetensi peserta didik pada mata pelajaran ini sangat penting. Hal ini karena mata pelajaran Dasar dasar Pakan Ternak merupakan pra syarat untuk mata pelajaran di kelompok C2 dan C3. Pada mata pelajaran ini proses pembelajaran disampaikan dengan metode praktik langsung dengan diawali penjelasan materi dari guru kemudian peserta didik melaksnakan praktik. Pemahaman pengetahuan faktual, konseptual, prosedural, dan metakognitif diperlukan peserta didik sebagai bekal untuk melaksanakan praktik. Peserta didik dinyatakan kompeten apabila memenuhi standar minimal yang dipersyarakat pada indicator dari setiap kompetensi dasar. Penetapan pencapaian nilai mengacu Pedoman Penilaian dan Pelaporn Hasil Belajar Peserta Didik SMK (Depdiknas : 2008). Guna meningkatkan kualitas peserta didik SMK Negeri 1 Cangkringan pada tahun pelajaran 2019/2020 telah menetapkan batas nilai KKM (Kriteria Ketuntasan Minimal) untuk mata pelajaran dasar-dasar pakan ternak adalah 75 (tujuh puluh lima).

Menurut Rifa'i dan Ani (2009) hasil belajar merupakan perubahan perilaku yang diperoleh peserta didik setelah mengalami kegiatan belajar Hasil belajar Dasar-dasar Pakan Ternak di SMK Negeri 1 Cangkringan kelas X ATR 2 masih rendah hal ini dikarenakan guru masih menggunakan model pembelajaran yang monoton dan konvensional. Pembelajaran hanya didominasi oleh guru dan siswa hanya pasif mendengarkan guru. Pembalajaran koperatif dapat membangkitkan minat pada peserta didik untuk terlibat didalamnya. Penggunaan model pembelajaran kooperatif learning diharapkan dapat meningkatkan hasil belajar. Model pembelajaran kooperatif tipe STAD merupakan pendekatan kooperatif learning yang menekankan pada aktivitas dan interaksi diantara 
siswa untuk saling memotivasi dan saling membantu dalam menguasai materi pelajaran guna mencapai prestasi yang maksimal (Endang Sadbudy dan I Made Nuryata, 2010). Rusman (2011) menyatakan bahwa pembelajaran kooperatif merupakan bentuk pembelajaran dengan cara siswa belajar dan bekerja dalam kelompok-kelompok kecil secara kolaboratif yang anggotanya terdiri dari empat sampai enam orang dengan struktur kelompok yang bersifat heterogen Model pembelajaran memegang peranan paling penting dalam mendokrak hasil belajar siswa. Penggunaan model yang tepat maka tujuan pembelajaran dapat tercapai.

Berdasarkan kondisi diatas, penulis ingin mencoba mengemukakan satu metode alternatif pemecahan masalah terhadap metode konvensional yang selama ini dipakai, dan sekaligus meningkatkan kualitas pembelajaran peserta didik, dengan menerapkan model pembelajaran kooperatif learning tipe STAD untuk kelancaran pelaksanaan pembelajaran pada kompetensi Dasar-dasar Pakan Ternak.

\section{METODE PENELITIAN}

Penelitian ini merupakan Penelitian Tindakan Kelas denggan menngunakan model yang dikembangkan Kurt Lewin. Menurut Kurt Lewin (dalam Arikumto, 2006) konsep pokok action researh terdiri dari empat komponen, yaitu: (1) perencanaan (planning), (2) tindakan (acting), (3) pengamatan (observing), dan (4) refleksi (reflecting). Langkah - langkah dalam siklus terdiri dari perencanaan tindakan, pelaksanaan tindakan, pengamatan dan refleksi.

Tahapan rancangan penelitian tindakan kelas menurut Stephen Kemmis dan Mc. Taggart (dalam Arikunto, 2006)dapat dilihat pada gambar dibawah ini.

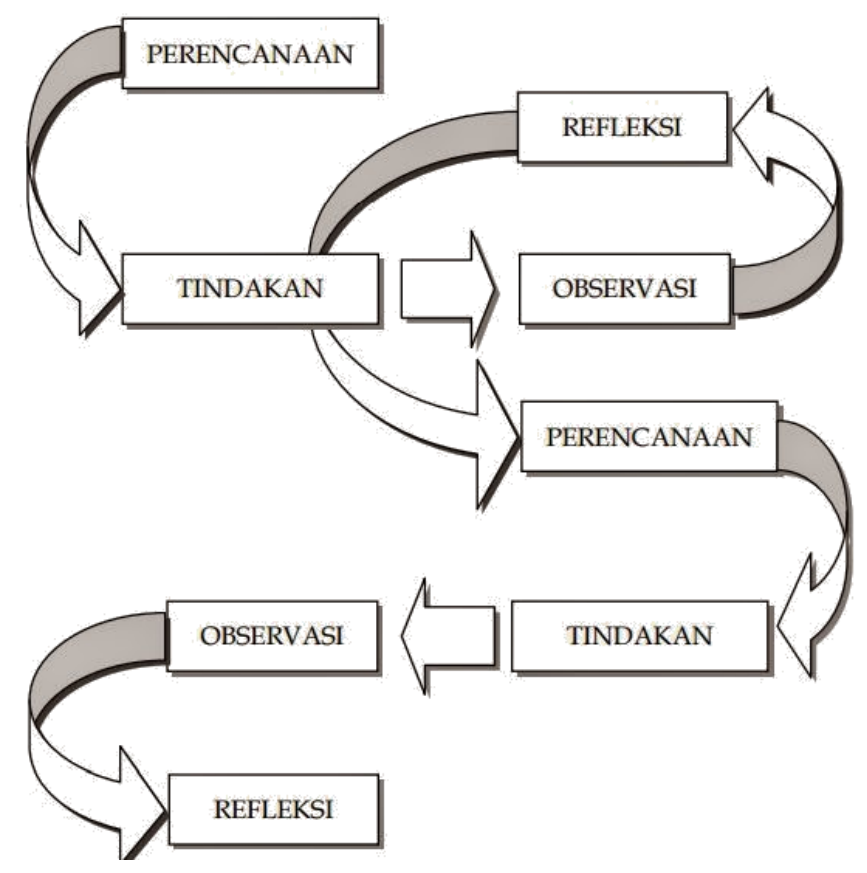

Gambar 1. Tahapan Penelitian Tindakan Kelas yang dikembangkan Kemmis \& Taggart.

Penelitian ini dilaksanakan pada bulan Agustus sampai dengan bulan November tahun 2019. Subyek penelitian tindakan kelas adalah peserta didik kelas X ATR 2 SMK Negeri 1 Cangkringan tahun pelajaran 2019/2020 yang berjumlah 35 orang peserta didik. Peneliti memilih kelas tersebut dijadikan subyek penelitian karena selain peneliti sebagai guru dikelas tersebut juga hasil belajar 
mata pelajaran Dasar-dasar Pakan Ternak masih rendah Dalam penelitian tindakan kelas ini pengambilan datanya menggunakan tes, observasi dan perilaku keterlibatan masing-masing peserta didik kelas X ATR 2 SMK Negeri 1 Cangkringan saat mengikuti pembelajaran terutama saat mempresentasikan di depan kelas. Alat pengumpulan data berupa butir soal tes dan lembar observasi. Ansalisa data yang digunakan adalah analisis diskriptif. Hasil belajar dianalisis dengsan analisis deskriptif komparatif yaitu membandingkan nilai tes antar siklus maupun dengan indikator keberhasilan. Observasi maupun wawancara dengan anlisis diskripti kualitati berdasarkan hasil observasi dan releksi.

Indikator Keberhasilan berdasarkan ketetapan sekolah sesuai kurikulum yang ada di SMK N 1 Cangkringan, yaitu seorang siswa telah tuntas belajar bila telah mencapai skor $75 \%$ atau nilai 75 , dan kelas disebut tuntas belajar bila di kelas tersebut terdapat $85 \%$ yang telah mencapai daya serap lebih dari atau sama dengan $85 \%$. Untuk menghitung persentase ketuntasan belajar digunakan rumus sebagai berikut:

$$
P=\frac{\sum \text { Siswa.yang.tuntas.belajar }}{\sum \text { Siswa }} \times 100 \%
$$

Apabila kelas belum mencapai ketuntasan belajar, maka penelitian tindakan dilanjutkan pada siklus berikutnya. Pembelajaran pada Siklus II merupakan hasil hasil refleksi siklus I, penulis dan kolaborator melakukan revisi proses pembelajaran, agar kualitas pembelajaran pada siklus II menjadi lebih baik, sesuai yang diharapkan. Proses yang dilakukan mulai dari perencanaan tindakan, pelaksanaan tindakan, observasi, dan refleksi, secara garis besar sama dengan siklussiklus sebelumnya.

\section{HASIL DAN PEMBAHASAN}

\section{Hasil}

\section{A. Deskripsi awal}

Deskripsi kondisi awal menggambarkan kondisi dan permasalahan yang ada di kelas yang akan diteliti. Kondisi awal diperoleh dari hasil pembelajaran sebelum menggunakan cooperative learning tipe STAD. Hasil pembelajaran awal diperoleh dengan melaksnakan pre test. Pre test digunakan peneliti sebagai acuan awal materi dasar dasar pakan ternak yang dikuasai peserta didik.

Hasil belajar yang peroleh peserta didik diawal masih kurang memuaskan peneliti, sehingga peneliti berdiskusi dengan observer untuk mengganti metode pembelajaran dari metode ceramah yang monoton dengan metode pembelajaran cooperative learning tipe STAD. Hal ini dapat dilihat pada tabel dibawah :

Tabel 1. Nilai kelompok pada kondisi awal

\begin{tabular}{lll}
\hline No. & Keterangan & Nilai \\
\hline 1 & Nilai tertinggi & 80 \\
2 & Nilai terendah & 58 \\
3 & Rata rata kelas & 71,63 \\
4 & Jumlah siswa tuntas & 13 \\
5 & Jumlah siswa belum tuntas & 22 \\
6 & Persentase ketuntasan belajar kelas & 37,14 \\
\hline
\end{tabular}


Hasil belajar siswa pada kondisi awal dapat dilihat pada grafik dibawah ini :

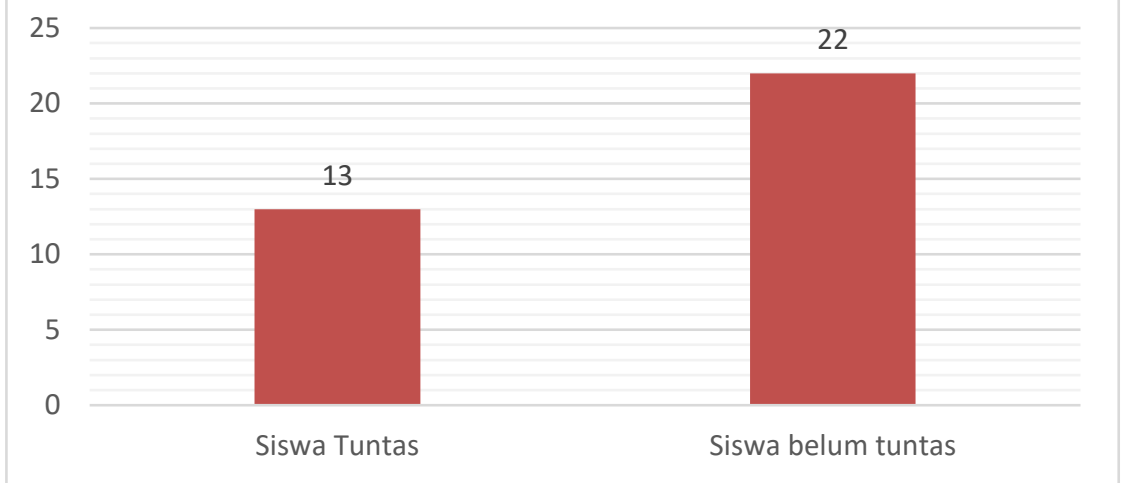

Gambar 2. Grafik hasil belajar kondisi awal

\section{B. Hasil Siklus 1}

Dilihat dari hasil pembelajaran pada kondisi awal yang kurang memuaskan peneliti maka peneliti mengubah métode pembelajaran. Peneliti menggunakan model pemebelajaran cooperative learning tipe STAD. Hasil belajar siklus I diperoleh dengan cara melakukan kuis yang dikerjakan siswa secara individual. Kuis dilaksnakan setelah siswa melakukan diskusi kelompok. Hasil belajar siklus I digunakan peneliti untuk memperoleh skor kemajuan kelompok dan pemberian penghargaan pada kelompok yang memperoleh skor kemajuan paling tinggi. Hasil belajar siswa diperoleh nilai sebagai berikut:

Tabel 2 Nilai kelompok pada siklus 1

\begin{tabular}{clcl}
\hline No & Nama Kelompok & $\begin{array}{c}\text { Skor kemajuan } \\
\text { kelompok }\end{array}$ & Predikat \\
\hline 1. & Ongole & 18 & Great temas \\
2. & Brahman & 26 & Super teams \\
3. & Yersey & 18 & Great teams \\
4. & Sahiwal & 16 & Graet teams \\
5. & Brownswiss & 12 & Good teams \\
6. & Simental & 16 & Great teams \\
7. & Limousine & 16 & Great teams \\
\hline
\end{tabular}

Hasil belajar siswa individual pada siklus 1 dapat dilihat pada tabel berikut :

Tabel 3 Nilai kelompok pada siklus 1

\begin{tabular}{lll}
\hline No. & Keterangan & Nila \\
& & \\
\hline 1. & Nilai tertinggi & 88 \\
2. & Nilai terendah & 55 \\
3. & Rata rata kelas & 75 \\
4. & Jumlah siswa tuntas & 28 \\
5. & Jumlah siswa belum tuntas & 7 \\
6. & Persentase ketuntasan belajar kelas & $80 \%$ \\
\hline
\end{tabular}


Hasil belajar siswa pada siklus I dapat dilihat pada grafik dibawah ini :

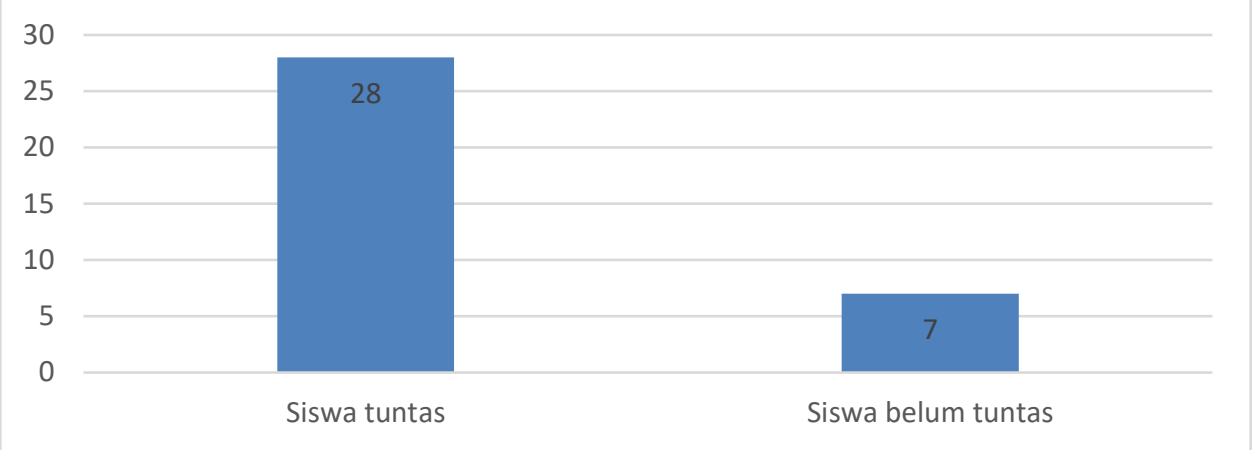

Gambar 3. Grafik Ketuntasan siswa pada siklus I

\section{Hasil siklus II}

Di pembelajaran siklus II sama dengan siklus I, tapi lebih dimantapkan baik guru maupun siswa. Guru menjadi lebih mahir dan siswa sudah tidak malu-malu dan takut dalam berdiskusi maupun melaksanakan presentasi. Hasil belajar yang peroleh peserta didik pada kondisi siklus II dapat dilihat pada tabel dibawah ini:

Tabel 4. Nilai kelompok pada siklus II

\begin{tabular}{cccc}
\hline No. & Nama Kelompok & $\begin{array}{l}\text { Skor kemajuan } \\
\text { kelompok }\end{array}$ & Ptedikat \\
\hline 1. & Ongole & 20 & Great temas \\
2. & Brahman & 24 & Super teams \\
3. & Yersey & 18 & Great teams \\
4. & Sahiwal & 26 & Super teams \\
5. & Brownswiss & 26 & Super teams \\
6. & Simental & 24 & Super teams \\
7. & Limousine & 24 & Super teams \\
\hline
\end{tabular}

Hasil belajar siswa individual pada siklus II dapat dilihat pada tabel berikut :

Tabel 5. Nilai individual pada siklus II

\begin{tabular}{lll}
\hline No. & Keterangan & Nilai \\
\hline 1. & Nilai tertinggi & 100 \\
2. & Nilai terendah & 71 \\
3. & Rata rata kelas & 83,97 \\
4. & Jumlah siswa tuntas & 33 \\
5. & Jumlah siswa belum tuntas & 2 \\
6. & Persentase ketuntasan belajar & 94,29 \\
& kelas & $\%$ \\
\hline
\end{tabular}


Hasil belajar siswa pada siklus II dapat dilihat pada grafik dibawah ini :

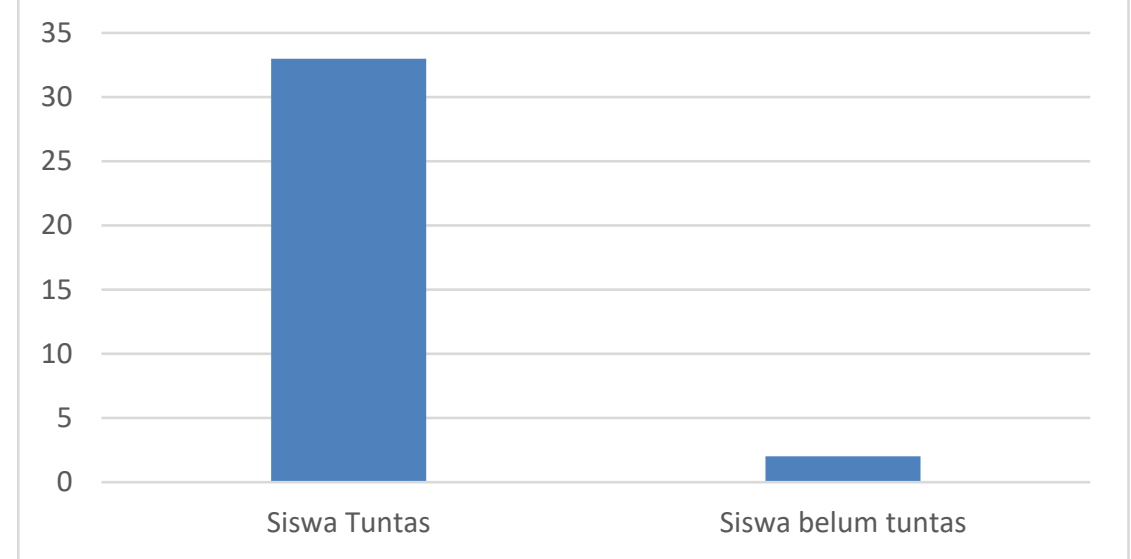

Gambar 4. Grafik Ketuntasan siswa pada siklus II

\section{Pembahasan}

Pembelajaran yang menerapkan model pembelajaran STAD langkah-langkah pembelajarannya diawali dengan presentasi materi yang dilakukan oleh guru, kemudian guru membagi kelas mejadi kelompok yang terdiri dari 5 siswa tiap kelompok dengan latar belakang yang heterogen. Menurut Isjoni dalam Tukiran Tuniredja tipe STAD yang dikembangkan oleh Slavin ini merupakan salah satu tipe kooperatif yang menekankan pada adanya aktivitas dan interaksi diantara siswa untuk saling memotivasi dan saling membantu dalam menguasai materi pelajaran guna mencapai hasil belajar maksimalSetiap kelompok di beri LKS untuk didiskusikan, setiap anggota kelompok bertanggung jawab pada kelompoknya agar semua anggota kelompok paham terhadap materi yang diberikan oleh guru. Setelah diskusi selesai siswa memepresentasikan hasil diskusi dan dilakukan pembahasan. Kemudian dilaksanakan kuis yang dikerjakan secara individu. Hasil yang didapat siswa dibandingkan dengan nilai mereka sebelumnya. Pada metode STAD guru menganalisa hasil yang diperoleh siswa untuk dijadikan nilai. Poin yang didapat kelompok tertinggi akan memperoleh penghargaan dari guru.

Dari hasil penelitian tindakan kelas yang dilakukan di peroleh peningkatan hasil pembelajaran dari kondisi awal, siklus I dan siklus II. Perbandingan hasil belajar kelompok siklus I dan siklus II dapat dilihat pada tabel berikut :

Tabel 6 Nilai kelompok pada siklus I dan siklus II

\begin{tabular}{llll}
\hline No. & $\begin{array}{l}\text { Nama } \\
\text { Kelompok }\end{array}$ & $\begin{array}{l}\text { Skor kemajuan } \\
\text { kelompok } \\
\text { siklus I }\end{array}$ & $\begin{array}{l}\text { Skor kemajuan } \\
\text { kelompok } \\
\text { Siklus II }\end{array}$ \\
\hline 1. & Ongole & 18 & 20 \\
2. & Brahman & 26 & 24 \\
3. & Yersey & 18 & 18 \\
4. & Sahiwal & 16 & 26 \\
5. & Brownswiss & 12 & 26 \\
6. & Simental & 16 & 24 \\
7. & Limousine & 16 & 24 \\
& & & \\
\hline
\end{tabular}


Skor kemajuan kelompok diperoleh dari rata rata nilai kemajuan tiap anggota kelompok. Dilihat dari tabel diatas skor kemajuan kelompik rata rata mengalami pengingkatan. Pada siklus I skor kemajuan kelompok tertinggi diperoleh kelompok Brahman dengan nilai 26. Pada siklus II skor kemajuan kelompok tertinggi diperoleh kelompok Sahiwal dan brownswiss. dari data penelitian diperoleh data kemampuan kelompok dalam berdiskusi meningkat, Hampir semua kelompok memperoleh nilai skor kelompok yang meningkat dibandingkan siklus I. Dari hasil ini dapat disimpulkan bahwa pada siklus II siswa sudah mulai mampu untuk melakukan diskusi kelompok, antar anggota kelompok sudah mulai berani untuk mengemukakan pendapat dan saling membantu sehingga hasil perolehan nilai menjadi maksimal. Pemberian penghargaan oleh guru kepada kelompok yang memperoleh nilai tinggi juga memotivasi siswa untuk memperoleh nilai yang maksimal sehingga nilai keolompok meningkat. Sesuai dengan yang dikemukakan oleh Sardiman (2007), bahwa saingan/kompetisi dapat mendorong belajar siswa. Persaingan, baik persaingan individual maupun kelompok dapat meningkatkan prestasi belajar siswa.

Perbandingan hasil belajar individual dari kondisi awal, siklus I dan siklus II dapat dilihat pada tabel berikut :

Tabel 7 Nilai kelompok pada siklus II

\begin{tabular}{lllll}
\hline No. & Keterangan & $\begin{array}{l}\text { Nilai } \\
\text { kondisi } \\
\text { awal }\end{array}$ & $\begin{array}{l}\text { Nilai siklus } \\
\text { I }\end{array}$ & $\begin{array}{l}\text { Nilai Siklus } \\
\text { II }\end{array}$ \\
\hline 1. & Nilai tertinggi & 80 & 88 & 100 \\
2. & Nilai terendah & 58 & 55 & 71 \\
3. & Rata rata kelas & 71,63 & 75 & 83,97 \\
4. & Jumlah siswa tuntas & 13 & 28 & 33 \\
5. & Jumlah siswa belum & 22 & 7 & 2 \\
& tuntas & & & \\
6. & Persentase & & & \\
& ketuntasan belajar & 37,14 & $80 \%$ & $94,29 \%$ \\
\hline
\end{tabular}

Dari tabel diatas dapat dilihât bahwa rata rata kelas pada siklus I (75) lebih baik dari kondisi awal $(71,63)$ dan pada siklus II $(83,97)$ lebih baik dari siklus I. Ketuntasan belajar juga mengalami peningkatan siklus I 80\% dan di siklus II 94,29\%. Pada siklus I ketuntasan belajar belum memenuhi kriteria yang diharpkan sedangkat di siklus II ketuntansan belajar sudah memenuhi kriteria yang diharpakan yaitu minimal 85\%. Dari hasil ini dapat disimpulkan bahwa penerapan model pembelajaran cooperative learning tipe stad dapat meningkatkan hasil belajar dasar-dasar pakan ternak kelas X ATR 2 SMK Negeri 1 Cangkringan.

Peningkatan hasil belajar siswa dalam penelitian ini juga didukung pendapat (Isjoni, 2011) yang menyatakan bahwa dengan diadakannya model pembelajaran kooperatif secara berkesinambungan dapat dijadikan sebagai sarana bagi guru untuk melatih dan mengembangkan aspek kognitif, afektif dan psikomotis siswa, khususnya keterampilan sosial siswa untuk bekal hidup di masyarakat.

Pada pembelajaran cooperative learning tipe stad menekankan pada aktivitas dan interaksi diantara siswa untuk saling memotivasi dan saling membantu dalam menguasai materi pelajaran guna mencapai prestasi. Karakteristik pembelajaran cooperative learning tipe adalah kerja secara kelompok, setiap siswa diharapkan meningkatkan hasil belajar kelompok dan individual. Pada pemebaljarn kelompok peran tutor sebaya sangat penting dalam kelompok siswa saling membantu agar tercapai hasil berlajar kelompok meningkat sehingga diharapakn hasil belajar individu juga meningkat, ini sesuai dengan pernyataan Slavin (2010) yang mengemukakan bahwa model pembelajaran kooperatif merujuk pada berbagai macam metode pengajaran dimana siswa bekerja 
dalam kelompok-kelompok kecil untuk membantu satu sama lainnya dalam mempelajari materi pelajaran. Hal ini menunjukkan dimana sistem kolaborasi menentukan dan sangat terbuka terhadap control dari guru. Pada saat beberapa mekanisme bagi analisis kelompok dan instropeksi merupakan dasar pendekatan yang berpusat pada guru namun collaborative learning adalah sangat berpusat kepada peserta didik (Endang Sadbudy Rahayu dan I Made Nuryata, 2010).

Hasil penelitian ini selaras dengan penelitian Sudana dengan judul Penerapan Model Pembelajaran Kooperatif Tipe STAD Untuk Meningkatkan Hasil Belajar IPA dan penelitian dari Sunilawati dengan judul Pengaruh Model Pembelajaran Kooperatif Tipe Stad Terhadap Hasil Belajar Matematika Ditinjau Dari Kemampuan Numerik Siswa Kelas IV SD.

\section{KESIMPULAN}

Dari hasil Penelitian Tindakan Kelas yang telash dilakukanmaka dapat diambil kesimpulan :

Penggunaan model pembelajaran Coopertif learning tipe STAD dapat meningkatkan hasil belajar siswa kelas X ATR 2. Kompetensi Dasar-dasar Pakan Ternak. Hal tersebut ditandai dengan adanya peningkatan prosentase ketuntasan kelas pada awal sebesar 37,14\%, pada siklus I sebesar $80 \%$ dan di siklus II sebesar 94,29\%. Penggunaan model pembelajran koopertif dimana aktifitas belajar terpusat pada siswa, siswa saling membantu dan saling mendukung, sehingga hasil belajar yang didapat akan merata dalam satu kelas. Aktifitas guru semakin meningkat mampu mengolah proses pembelajaran menjadi lebih baik, aktfi, kreatif, efektif dan menyenangkan

\section{DAFTAR PUSTAKA}

Arikunto, S., dkk. (2012). Penelitian Tindakan Kelas. Jakarta: Bumi Aksara

Depdiknas, (2008). Model-model Pembelajaran Sekolah Menengah Kejuruan. Dit PSMK Depdiknas. Jakarta.

Isjoni, (2011). Pembelajaran Kooperatif. Yogyakarta: Pustaka Pelajar

Rahayu, E.S., \& Nuryanta, M. I. (2011). Pengembangan Soft Skill di SMK, Jakarta Timur : Sekarmita.

Rifa'i, Achmad dan Catharina Tri Anni. (2009)_. Psikologi Pendidikan. Semarang: Universitas Negeri Semarang Press

Rusman,. (2014) Model-Model Pembelajaran: Mengembangkan Profesionalisme Guru, Jakarta: Rajawali Pers.

Salvin, S.E., 2010. Cooperative Learning : Teori, Riset dan Praktik. Jakarta: Nuramedia.

Sardiman, A.M. (2007). Interaksi dan Motivasi Belajar Mengajar. Jakarta: PT Raja Grafindo Persada

Sudana, I. 2017. Penerapan Model Pembelajaran Kooperatif Tipe STAD Untuk Meningkatkan Hasil Belajar IPA. Jurnal Ilmiah Sekolah Dasar. Vol 1 No 1

Sunilawati, dkk. 2013. Pengaruh Model Pembelajaran Kooperatif Tipe Stad Terhadap Hasil Belajar Matematika Ditinjau Dari Kemampuan Numerik Siswa Kelas Iv Sd, e-Journal Program Pascasarjana Universitas Pendidikan Ganesha Jurusan Pendidikan Dasar, (Volume 3 Tahun 2013)

Tukiran Taniredja, dkk. (2012). Model-Model Pembelajran Inovatif. Bandung: Alfabeta. 